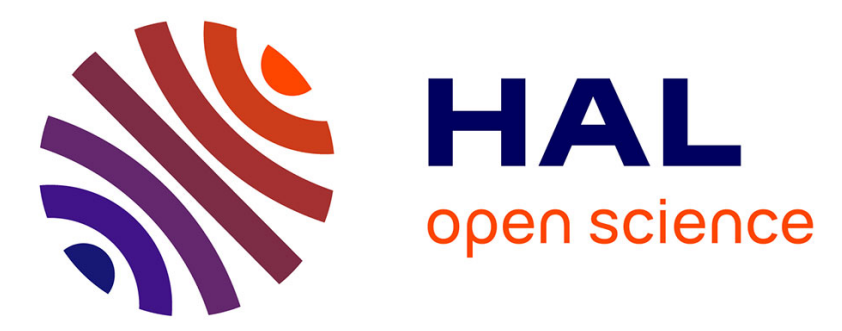

\title{
First case of invasive breast cancer following prophylactic bilateral skin sparing mastectomy in a BRCA1 mutation carrier
}

W. Maarse, Y. Jonasse, M.G.E.M. Ausems, M.E.I. Schipper, R. van Hillegersberg

\section{To cite this version:}

W. Maarse, Y. Jonasse, M.G.E.M. Ausems, M.E.I. Schipper, R. van Hillegersberg. First case of invasive breast cancer following prophylactic bilateral skin sparing mastectomy in a BRCA1 mutation carrier. EJSO - European Journal of Surgical Oncology, 2009, 35 (9), pp.1016. 10.1016/j.ejso.2009.03.006 . hal-00556290

\section{HAL Id: hal-00556290 \\ https://hal.science/hal-00556290}

Submitted on 16 Jan 2011

HAL is a multi-disciplinary open access archive for the deposit and dissemination of scientific research documents, whether they are published or not. The documents may come from teaching and research institutions in France or abroad, or from public or private research centers.
L'archive ouverte pluridisciplinaire $\mathbf{H A L}$, est destinée au dépôt et à la diffusion de documents scientifiques de niveau recherche, publiés ou non, émanant des établissements d'enseignement et de recherche français ou étrangers, des laboratoires publics ou privés. 


\section{Accepted Manuscript}

Title: First case of invasive breast cancer following prophylactic bilateral skin sparing mastectomy in a BRCA1 mutation carrier

Authors: W. Maarse, Y. Jonasse, M.G.E.M. Ausems, M.E.I.

Schipper, R. van Hillegersberg

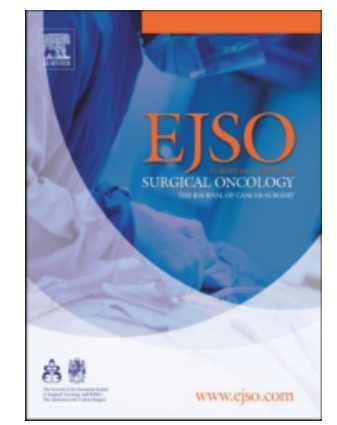

PII: $\quad$ S0748-7983(09)00105-X

DOI: $\quad$ 10.1016/j.ejso.2009.03.006

Reference: $\quad$ YEJSO 2814

To appear in: European Journal of Surgical Oncology

Received Date: 18 February 2009

Revised Date: 11 March 2009

Accepted Date: 17 March 2009

Please cite this article as: Maarse W, Jonasse Y, Ausems MGEM, Schipper MEI, van Hillegersberg R. First case of invasive breast cancer following prophylactic bilateral skin sparing mastectomy in a BRCA1 mutation carrier, European Journal of Surgical Oncology (2009), doi: 10.1016/j.ejso.2009.03.006

This is a PDF file of an unedited manuscript that has been accepted for publication. As a service to our customers we are providing this early version of the manuscript. The manuscript will undergo copyediting, typesetting, and review of the resulting proof before it is published in its final form. Please note that during the production process errors may be discovered which could affect the content, and all legal disclaimers that apply to the journal pertain. 


\title{
First case of invasive breast cancer following prophylactic bilateral skin sparing mastectomy in a BRCA1 mutation carrier
}

\author{
W. Maarse ${ }^{a}$ (MD), Y. Jonasse ${ }^{a}$ (MD), M.G.E.M. Ausems ${ }^{b}$ (MD, PhD), M.E.I. Schipper ${ }^{c}$
}

(MD), R. van Hillegersberg ${ }^{\mathrm{d}}$ (MD, PhD).

${ }^{\mathrm{a}}$ The Department of Plastic, Reconstructive and Hand Surgery, University Medical Centre

Utrecht, The Netherlands

b The Department of Medical Genetics, University Medical Centre Utrecht, The Netherlands

${ }^{\mathrm{c}}$ The Department of Histopathology, University Medical Centre Utrecht, The Netherlands

d The Department of Surgery, University Medical Centre Utrecht, The Netherlands

Corresponding author:

Prof. dr. R. van Hillergersberg

Department of Surgery (G04.228),

University Medical Center Utrecht,

Heidelbergaan 100, 3584 CX Utrecht, the Netherlands

Email: r.vanhillegersberg@umcutrecht.nl

Fax: 0887558022

Running head: Residual breast tissue following BPM

Keywords: breast cancer, BRCA, prophylactic mastectomy, case report, skin sparing mastectomy 


\section{Introduction}

Since BRCA1 and BRCA2 mutation carriers face a cumulative breast cancer risk as high as $65 \%$ (1) to $82 \%$ (2), there are several options to reduce this risk. These are regular surveillance, chemoprevention and prophylactic surgery. Bilateral prophylactic mastectomy (BPM) results in the greatest breast cancer risk reduction (3-5), but it is an irreversible intervention. Simultaneous reconstruction in the same session is accompanied by a considerable complication rate (6). In general, a subcutaneous mastectomy, which preserves the nipple-areolar complex, is not recommended, as premalignant ductal tissue remains in situ(7). Even a total mastectomy can never completely remove all breast tissue. We present a case of breast cancer following a prophylactic total mastectomy. 


\section{Case report}

In 1999 presymptomatic DNA testing revealed that a 28-year-old healthy woman was carrier of a BRCA1 mutation (c.5266dupC). After the DNA test she decided to have a prophylactic mastectomy, with immediate reconstruction using subpectoral implants. The mastectomy was performed in 2002, removing the gland including the superficial or subdermal fascia, the axillary tail, the nipple-areolar complex, and the fascia of the pectoral muscle. Histopathological examination of both specimen showed no sign of malignancy.

Five years later she $(\mathrm{G} 2 \mathrm{P} 2)$ presented with a $2-3 \mathrm{~cm}$ palpable, firm and mobile lesion in the right axilla, just located on the edge of the right pectoral muscle. A diagnostic needle biopsy revealed a poorly differentiated adenocarcinoma, resembling a breast carcinoma. Removal of the tumour including all the residual breast tissue, overlying skin and the subpectoral encapsulated implant on the right side followed. In the same session a right axillary lymph node dissection was performed. Histopathological examination of the rest-mastectomy showed, first of all, residual breast tissue at the level of the pectoral fascia and at the ventral side covered by a traumatic proliferation of peripheral nerve tissue (traumatic neuroma), just indicating the surgeon 'was there before'. The tumour, originating from the residual breast tissue, was a receptor and Her2Neu negative invasive ductal carcinoma of 18mm diameter, with a high mitotic index (MAI 45) and as poorly differentiated (Bloom \& Richardson grade III) as could be expected in BRCA1 mutation carriers. All 22 axillary lymph node were tumour negative. Mirror-biopsy of a left axillary lymph node revealed no malignancy. Postoperative radiotherapy of the thoracic wall was additionally performed and a control mammograph scheme for the residual breast tissue at the left side was offered. Radiotherapy on the right thorax was performed. At present, twelve months postoperatively, she is without signs of tumour recurrence. 


\section{Discussion}

Prophylactic mastectomy in BRCA mutation carriers significantly reduces the risk of breast cancer, but it does not eliminate it. Although complete removal of breast tissue is not possible, there is no general advice on screening after prophylactic bilateral mastectomy.

\section{Risk reducing effect of $B P M$}

Several studies specifically investigate bilateral prophylactic mastectomy in BRCA carriers. There have been no prospective clinical trials. From an ethical consideration, it is not possible to randomize these women. Hartmann et al. (8) conducted a prospective study of 214 women who were considered at high or moderate risk and who had prophylactic mastectomy. Twenty-six were carriers of BRCA1 or BRCA2 gene mutations. None of the carriers developed breast cancer at a mean follow up of 13.4 years, resulting in a relative risk reduction of $85 \%$ to $100 \%(95 \%$ CI: $41.4-100 \%)$. In a short follow-up study by MeijersHeijboer et al, (4) 139 BRCA1/2 mutation carriers were followed for a mean of 2.9 years. Seventy-six women underwent BPM, and 63 remained under close surveillance. No breast cancer developed in the BPM-group, compared to eight cancers in the 63 patients in the same period, yielding $100 \%$ risk reduction. The risk-reducing effect of prophylactic salpingooophorectomy (PSO), which has a risk reducing effect by almost $72 \%$ only in BRCA2 mutation carriers (9), cannot be isolated from the risk reducing effect of BPM in this study. Rebbeck et al. (5) prospectively followed 105 BRCA mutation carriers after BPM and compared with 378 controls who did not have the procedure. After a mean follow-up of 6.4 years there was a relative breast cancer risk reduction of 95\% in those who had PSO and 90\% in those who had intact ovaries. Taken together, these studies confirm a $90 \%$ to $95 \%$ reduction in breast cancer risk after BPM in BRCA carriers. 


\section{Type of mastectomy and residual breast tissue}

There is some debate regarding which type of surgical procedure has to be performed in BPM. In general, subcutaneous mastectomy, which preserves the nipple-areola complex and therefore has a better cosmetic outcome (10), is not optimal. This is because subcutaneous mastectomy, compared to a total mastectomy, leaves more substantial breast tissue intact. Histological studies show that more than fifty percent of patients who underwent skin-sparing mastectomy (SSM) have residual terminal duct lobular units (TDLU's) in skin flaps(11;12), as well as an infrequent occurrence in the nipple papilla (7). Torresan et al. (12) first performed a SSM, and then removed the skin flap that would have remained in forty-two breast cancer patients, essentially converting the procedure to a conventional mastectomy. They found TDLU's in 59.5\% of their skin flaps and the presence of residual breast tissue was significantly associated with a skin flap thickness $>5 \mathrm{~mm}$. In leaving more breast tissue behind, the concern of malignant transformation becomes more extensive. In addition breast cancers arising in BRCA-carriers have a faster growth rate in comparison to sporadic breast cancer (13). More than fifty percent of breast cancers are found in the upper outer region(14) and tumours can appear in ectopic axillary breast tissue (2-6 \%), which is rare though(15).

Even in total mastectomy, which is less difficult through a more extensive incision, complete removal and identifying the margins of breast tissue macroscopically is not easy during surgery. Especially in the axillary tail, where the breast cancer also was found in our case. The breast tissue extends laterally into the axillary tail, sometimes past the border of the latissimus dorsi muscle (16). By dissecting through the clavipectoral fascia, the edge of the breast tissue can be identified (17). Removal of the pectoral major fascia is also performed as breast tissue may penetrate into this muscle. To preserve the subdermal plexus and avoid flap necrosis in SSM, it is recommended to dissect just above the superficial layer (SL) of the superficial fascia of the breast, which encloses the mammary gland ventrally. However, according to the 
histological research of Beer et al.(18) the SL is absent in approximately 44\%. Even if the SL is present, the distance to the overlying skin is usually very small. In $50 \%$ of the patients the distance was $<1.1 \mathrm{~mm}$, which is too small to leave viable skin flaps. These results imply another anatomic difficulty in removing all breast tissue in SSM.

The theory that the amount of breast tissue is proportional to cancer risk is unstable, although an observational study found a reduced breast cancer risk in proportion to the amount of breast removed in breast reduction operations (19). Several studies demonstrate the oncologic safety of SSM (20;21), with a local recurrence rate similar to that of conventional mastectomy. For nipple-sparing mastectomy there is also growing positive evidence (22;23), but longer follow-up studies are needed.

By preserving the native breast envelope and the inframammary ridge, positioning and shaping of the reconstructed breast are facilitated. SSM also facilitates a favourable functional outcome as it enables most of the sensation of the skin of the breast (24).

\section{Our experiences}

In our clinic we offer skin sparing mastectomy. From 1991 till 2007 we have performed 40 prophylactic mastectomies. All were high risk women, of whom 34 were BRCA mutation carriers. This was the first presenting case with breast cancer after BPM. It raises the question whether our technical procedure in removing the breast tissue was adequate in this patient. There were no unexpected microscopic (pre) malignant findings in prophylactically removed breasts. In our opinion, routine use of sentinel lymph node biopsy is not warranted, which is supported in the paper of Heemskerk-Gerritsen et al.(25).

\section{Conclusion}

Women should be well informed about the significant risk reducing effect of BPM, but also 
that the risk of developing breast cancer cannot be completely eliminated. Moreover, we have to be vigilant that delayed malignancy can occur. Utmost important is meticulous surgical technique to ensure complete excision of all breast tissue.

\section{Conflict of interest}

The authors state that they have no conflict of interest. 


\section{Reference List}

1. Antoniou A, Pharoah PD, Narod S, Risch HA, Eyfjord JE, Hopper JL, Loman N, Olsson H, Johannsson O, Borg A, Pasini B, Radice P, Manoukian S, Eccles DM, Tang N, Olah E, nton-Culver H, Warner E, Lubinski J, Gronwald J, Gorski B, Tulinius H, Thorlacius S, Eerola H, Nevanlinna H, Syrjakoski K, Kallioniemi OP, Thompson D, Evans C, Peto J, Lalloo F, Evans DG, Easton DF. Average Risks of Breast and Ovarian Cancer Associated With BRCA1 or BRCA2 Mutations Detected in Case Series Unselected for Family History: a Combined Analysis of 22 Studies. Am J Hum Genet 2003; 72(5): 1117-30.

2. King MC, Marks JH, Mandell JB. Breast and Ovarian Cancer Risks Due to Inherited Mutations in BRCA1 and BRCA2. Science 2003; 302(5645): 643-6.

3. Hartmann LC, Schaid DJ, Woods JE, Crotty TP, Myers JL, Arnold PG, Petty PM, Sellers TA, Johnson JL, McDonnell SK, Frost MH, Jenkins RB. Efficacy of Bilateral Prophylactic Mastectomy in Women With a Family History of Breast Cancer. $N$ Engl $J$ Med 1999; 340(2): 77-84.

4. Meijers-Heijboer H, van GB, van Putten WL, Henzen-Logmans SC, Seynaeve C, Menke-Pluymers MB, Bartels CC, Verhoog LC, van den Ouweland AM, Niermeijer MF, Brekelmans CT, Klijn JG. Breast Cancer After Prophylactic Bilateral Mastectomy in Women With a BRCA1 or BRCA2 Mutation. $N$ Engl J Med 2001; 345(3): 159-64.

5. Rebbeck TR, Friebel T, Lynch HT, Neuhausen SL, van ', V, Garber JE, Evans GR, Narod SA, Isaacs C, Matloff E, Daly MB, Olopade OI, Weber BL. Bilateral Prophylactic Mastectomy Reduces Breast Cancer Risk in BRCA1 and BRCA2 Mutation Carriers: the PROSE Study Group. J Clin Oncol 2004; 22(6): 1055-62.

6. Gabriel SE, Woods JE, O'Fallon WM, Beard CM, Kurland LT, Melton LJ, III. Complications Leading to Surgery After Breast Implantation. N Engl J Med 1997; 336(10): 677-82.

7. Stolier AJ, Wang J. Terminal Duct Lobular Units Are Scarce in the Nipple: Implications for Prophylactic Nipple-Sparing Mastectomy: Terminal Duct Lobular Units in the Nipple. Ann Surg Oncol 2008; 15(2): 438-42.

8. Hartmann LC, Sellers TA, Schaid DJ, Frank TS, Soderberg CL, Sitta DL, Frost MH, Grant CS, Donohue JH, Woods JE, McDonnell SK, Vockley CW, Deffenbaugh A, Couch FJ, Jenkins RB. Efficacy of Bilateral Prophylactic Mastectomy in BRCA1 and BRCA2 Gene Mutation Carriers. J Natl Cancer Inst 2001; 93(21): 1633-7.

9. Kauff ND, Domchek SM, Friebel TM, Robson ME, Lee J, Garber JE, Isaacs C, Evans DG, Lynch H, Eeles RA, Neuhausen SL, Daly MB, Matloff E, Blum JL, Sabbatini P, Barakat RR, Hudis C, Norton L, Offit K, Rebbeck TR. Risk-Reducing SalpingoOophorectomy for the Prevention of B. J Clin Oncol 2008; 26(8): 1331-7.

10. Metcalfe KA, Semple JL, Narod SA. Time to Reconsider Subcutaneous Mastectomy for Breast-Cancer Prevention? Lancet Oncol 2005; 6(6): 431-4. 
11. Cao D, Tsangaris TN, Kouprina N, Wu LS, Balch CM, Vang R, Argani P. The Superficial Margin of the Skin-Sparing Mastectomy for Breast Carcinoma: Factors Predicting Involvement and Efficacy of Additional Margin Sampling. Ann Surg Oncol 2008; 15(5): 1330-40.

12. Torresan RZ, dos Santos CC, Okamura H, Alvarenga M. Evaluation of Residual Glandular Tissue After Skin-Sparing Mastectomies. Ann Surg Oncol 2005; 12(12): 1037-44.

13. Armes JE, Trute L, White D, Southey MC, Hammet F, Tesoriero A, Hutchins AM, Dite GS, McCredie MR, Giles GG, Hopper JL, Venter DJ. Distinct Molecular Pathogeneses of Early-Onset Breast Cancers in BRCA1 and BRCA2 Mutation Carriers: a PopulationBased Study. Cancer Res 1999; 59(8): 2011-7.

14. Sohn VY, Arthurs ZM, Sebesta JA, Brown TA. Primary Tumor Location Impacts Breast Cancer Survival. Am J Surg 2008; 195(5): 641-4.

15. Giron GL, Friedman I, Feldman S. Lobular Carcinoma in Ectopic Axillary Breast Tissue. Am Surg 2004; 70(4): 312-5.

16. Goldman LD, Goldwyn RM. Some Anatomical Considerations of Subcutaneous Mastectomy. Plast Reconstr Surg 1973; 51(5): 501-5.

17. Temple WJ, Lindsay RL, Magi E, Urbanski SJ. Technical Considerations for Prophylactic Mastectomy in Patients at High Risk for Breast Cancer. Am J Surg 1991; 161(4): 413-5.

18. Beer GM, Varga Z, Budi S, Seifert B, Meyer VE. Incidence of the Superficial Fascia and Its Relevance in Skin-Sparing Mastectomy. Cancer 2002; 94(6): 1619-25.

19. Brinton LA, Persson I, Boice JD, Jr., McLaughlin JK, Fraumeni JF, Jr. Breast Cancer Risk in Relation to Amount of Tissue Removed During Breast Reduction Operations in Sweden. Cancer 2001; 91(3): 478-83.

20. Ho CM, Mak CK, Lau Y, Cheung WY, Chan MC, Hung WK. Skin Involvement in Invasive Breast Carcinoma: Safety of Skin-Sparing Mastectomy. Ann Surg Oncol 2003; 10(2): 102-7.

21. Kroll SS, Khoo A, Singletary SE, Ames FC, Wang BG, Reece GP, Miller MJ, Evans GR, Robb GL. Local Recurrence Risk After Skin-Sparing and Conventional Mastectomy: a 6-Year Follow-Up. Plast Reconstr Surg 1999; 104(2): 421-5.

22. Margulies AG, Hochberg J, Kepple J, Henry-Tillman RS, Westbrook K, Klimberg VS. Total Skin-Sparing Mastectomy Without Preservation of the Nipple-Areola Complex. Am J Surg 2005; 190(6): 907-12.

23. Chung AP, Sacchini V. Nipple-Sparing Mastectomy: Where Are We Now? Surg Oncol 2008.

24. Meretoja TJ, Rasia S, von Smitten KA, sko-Seljavaara SL, Kuokkanen HO, Jahkola TA. Late Results of Skin-Sparing Mastectomy Followed by Immediate Breast Reconstruction. Br J Surg 2007; 94(10): 1220-5. 
25. Heemskerk-Gerritsen BA, Brekelmans CT, Menke-Pluymers MB, van Geel AN, Tilanus-Linthorst MM, Bartels CC, Tan M, Meijers-Heijboer HE, Klijn JG, Seynaeve C. Prophylactic Mastectomy in BRCA1/2 Mutation Carriers and Women at Risk of Hereditary Breast Cancer: Long-Term Experiences at the Rotterdam Family Cancer Clinic. Ann Surg Oncol 2007; 14(12): 3335-44. 